\title{
'n Soeke na menslikheid en Goddelikheid by Jesus: Chalcedon in die twintigste eeu verwoord
}

\author{
J Otto \\ Deeltydse dosent: Departement Dogmatiek en Christelike Etiek (Afd A) \\ Universiteit van Pretoria
}

\begin{abstract}
Searching for the humanity and divinity of Jesus: Chalcedon translated into twentieth century language

This article investigates the possibility of rephrasing the Chalcedon formula in such a manner that it will still be acceptable in the postmodern era, while at the same time not departing from its theological essence. Different views on humanity are compared. This is followed by a comparison of different views on divinity. The point is made that the perspective of the interpreter influences the results. This means that each new generation will view matters from a different perspective. The results indicate that a more dynamic way of rephrasing Chalcedon can contribute greatly to its acceptance today. The rephrasing is done here within the frame of reference of Wolfhart Pannenberg's understanding of history.
\end{abstract}

\section{INLEIDING}

In hierdie artikel is die tese dat Chalcedon belangrike spreekreëls bied vir die Christologie. Die noodsaak van hierdie spreekreëls gaan aangedui word deur eers by wyse van 'n sintese standpunte aangaande die konsepte 'menslik' en 'Goddelik' met mekaar te vergelyk om tot 'n eie formulering te kom. Vervolgens word die Chalcedonformule aan die hand van hierdie benadering geëvalueer. Die doel hiermee is om aan te dui dat Chalcedon 'n noodsaaklike vooronderstelling aan teoloë bied ten opsigte van hulle verstaan van die twee nature van Jesus Christus as ware mens en ware God. Die artikel maak gebruik van die spreekreëls wat Chalcedon bied om sekere aspekte van die twee nature te beklemtoon.

* Hiendie artikel is 'n verwerking van die resultate van die DD-proefskrif, 'Chalcedon op pad na die 21e ceu: 'n Soeke na 'n eietydse verwoording van die twee nature leer', ingedien en aanvaar as deel van die verseistes vie die DD-graad (1997), Departement Dogmatiek en Christelike Etiek, Fakulteit Teologie (Afd A), Universiteit van Pretoria, onder leiding van prof dr J H Koekemoer. 
Die spreekreels wat Chalcedon stel, kan soos volg opgesom word: Jesus is die een Seun, volledig wat betref sy Goddelikheid en volledig wat betref sy menslikheid, ware God en ware mens. Jesus bestaan uit 'n redelike siel en liggaam, een in substansie met sy Vader sover dit die Goddelike betref, en een in substansie met die mensdom sover dit die menslike betref. Jesus is die mense in alles gelyk, uitgesonderd die sonde. Jesus het 'n buite-tydse bestaan, maar het mens geword om die mensdom se saligheid te verseker. Tog moet die twee nature in die een persoon erken word. Die twee nature (die Goddelike en menslike) is sonder vermenging, sonder verandering, sonder verdeeldheid en sonder skeiding in die een persoon Jesus Christus.

\section{Die menslikheid van Jesus}

Sonder om die antropologie te verabsoluteer, is dit tog nodig om vanuit 'n teologiese perspektief die vraag na die essensie van menswees te vra. Die verskillende beelde van menswees gee aanleiding tot uiteenlopende benaderings. In 'n vorige eeu is die mens gesien as bedreig deur die natur en in konflik met die natulirlike kragte. Die mens is die maatstaf vir kennis. Die bekende uitspraak van Descartes cogito ergo sum dui op die menslike denke as die toonaangewende. Die subjek-objek skema se grondslag moet by Descartes gesoek word. Hierdie siening is egter aan die verdwyn en die mens word gesien in harmonie met die natuur en tegelyk ook afhanklik van die natuur. Menslikheid is al aan emosionaliteit, aan liggaamlikheid, aan interne denkprosesse en vele ander aspekte van menswees gekoppel. Menswees kan selfs aan die besit van 'n siel gekoppel word (Swinburne 1989:55). Baie van hierdie beelde van menswees het meer met metafisiese spekulasie as met die werklikheid te doen.

\subsection{Sondigheid as menslikheid}

Hick (1984:57) het myns insiens 'n simplistiese siening van sonde, gesien in die lig van sy bespreking van die inkarnasie van God. Volgens hom is een moontlike inkarnasie van God die morele inkarnasie, en hy stel dit as 'n moontlike manier waarop Jesus mens geword het. Direk daarna stel hy 'n paar van die sogenaamde morele flaters wat Jesus na bewering gemaak het, waaronder rassisme en chauvinisme. Die gevolgtrekking waartoe dit hom laat kom, is dat Jesus 'n sondaar was soos die res van die mense rondom Hom. Sonde en sondigheid is egter nie so 'n eenvoudige saak as wat Hick dit sien nie. Nog minder is sondigheid die essensie van menswees.

Sonde is al op verskillende maniere beskryf. In sy oorsig van beelde van sonde skenk Otto Weber (1981:582-7) in historiese volgorde aandag aan 'n paar konsepte van sonde. Die eerste en waarskynlik oudste verklarings van die bose is die gedagte van 
dualisme in die sin dat die wêreld die slagveld van die stryd tussen goed en kwaad is. Proporsioneel kom dit daarop neer dat die mens of minder skuld dra en, afhangend van die betrokke denkrigting, die reg en vryheid tot keuse het, $6 f$ as pion in die stryd gebruik word. 'n Meer subtiele vorm van hierdie dualisme word teruggevind in 'n gedagterigting wat sensualiteit of seksualiteit as sonde sien (Weber 1981:583). Hierdie denke word afgelei van die dualisme tussen gees en vlees, met die vlees en drifte van die vlees as die verkeerde of bose. 'Vleeslik' beteken nie noodwendig net die verkeerde nie, maar kan ook swakker of geringer beteken. Hierdie benadering herinner baie aan die dualisme van Plato (vgl Stumpf 1975:66), wat waarskynlik gesien kan word as die oerbron van alle dualistiese denke. Hierdie Platoniese gedagte is deur die Neo-Platonisme (Weber 1981:583) verder gevoer. In so 'n benadering gaan dit oor 'n gebrek aan iets goeds in die dader. Sonde kan ook gesien word as iets wat dialekties staan teenoor die goeie, in plaas van as 'n gebrek aan die goeie.

Otto Weber (1981:580) stel dat kennis van sonde verbind is aan vergifnis. 'n Mens ken sonde slegs deur God se genade heen. Dit moet duidelik gestel word dat hierdie sonde nie die onreg van een mens teenoor 'n ander na aanleiding van 'n stel ooreengekome reëls is nie. Die sonde waarvan hier sprake is, is die sonde teen God. Edmund Schlink (1985:144-145) sien die saak in soortgelyke lig wanneer hy stel dat die mens se sonde deur God se heilsdaad aan die mensdom bekend word. Sonde is niks anders as ongegronde ondankbaarheid teenoor God nie. Skulderkentenis en lofprysing aan God hoort daarom saam. Die leer van die sonde is volgens hom die belydenis van gesamentlike skuld as selfverheffing teenoor God.

Vanuit 'n ander perspektief gesien is Weber (1981:592) se onderskeid tussen sonde as persoonlike sonde en sonde as sonde voor God belangrik vir 'n regte verstaan van die verband tussen sonde en menslikheid. Indien volhard word met die stelling dat die mens imago Dei geskep is, kan dit nie anders as dat die sonde so gesien sal word nie. Sonde is opstandigheid teenoor God, dit is persoonlike sonde. Dit beteken verder dat sonde nie onties deel van die mens is nie.

\subsubsection{God se sonde}

Om te stel dat sonde nie ontologies gesien, deel van die mens is nie, is om Hick (1984: 59) se stelling (Jesus is menslik want Hy het gesondig) gedeeltelik te beantwoord, aangesien daar 'n verdere implikasie van sy stelling sou kon wees. Sonde is ongehoorsaamheid aan God. Hick vervlak sonde tot morele wandade en sien nie raak dat sonde persoonlike sonde in verhouding tot God is nie. Hy lees iets raak wat Jesus ervaar of gedoen het, en stel dan dat dit sonde is. God self ontvlam in toorn (vgl Ps 78:31) oor die sonde. Volgens Hick sou dit moes beteken dat God gesondig het. 
Die punt is dat sonde opstandigheid teen God is en teen daardie agtergrond moet Jesus se dade geëvalueer word. Saam met Pannenberg (1994:363) kan daar dan gestel word dat Jesus in gehoorsaamheid aan God geleef het, deur Homself te onderwerp aan God. Gehoorsaamheid aan God staan teenoor sondigheid, maar nie teenoor menslikheid nie.

Om 'n vrye keuse te kan uitoefen is 'n wesenskenmerk van die mens. Die mens kan hierdie kenmerk egter gebruik in selfverheffing (Schlink 19985:122). Jesus in die menslike situasie het dieselfde vryheid van keuse gehad, maar dit gebruik om aan God gehoorsaam te bly. Dit sou aan die een kant daarom regverdigbaar wees om te stel dat Jesus ware mens was, aangesien Hy vryheid van keuse gehad het. Sondigheid is nie noodwendig gelyk aan menslikheid nie en daarom kan daar nie gestel word dat Jesus ware mens was na aanleiding van hierdie beeld van menslikheid nie. Verder moet dit gestel word dat Chalcedon reeds gestel het dat Jesus die mensdom in alles gelyk was, uitgesluit die sonde.

\subsection{Sterflikheid as menslikheid}

Die verband tussen sonde en dood is lank reeds bekend. Romeine 6:23 stel hierdie verband baie duidelik en volgens Genesis 3:19 word die dood gesien as die straf vir die opstandigheid van die mens. Vryheid van keuse is deel van die skeppingsorde, en die mens het hierdie keuse verkeerd gebruik deur teen God te kies. Dood as die straf vir die verkeerde keuse (sonde) is Bybels aanduibaar. Dit moet nou as 'n moontlikheid gestel word dat sterflikheid eie aan die mens gesien word. God se onsterflikheid en die menslike sterflikheid staan in so ' $n$ benadering as pole teenoor mekaar. Dit sal beteken dat Jesus ware mens was op grond van die feit dat $\mathrm{Hy}$ aan die knuis gesterf het. Hierdie benadering beperk menslikheid slegs tot een dimensie van die spektrum van menswees. Die mens staan wel reeds van geboorte af onder die teken van die dood, maar dit beteken nie dat die mens eers mens word wanneer hy of sy tot sterwe kom nie.

Om sterflikheid as aanduiding van die laaste punt van menslikheid te sien, is om die metafisiese teenstelling tussen God se ewigheid en die mens se tydelike bestaan te gebruik om 'n argument te staaf. Historiese navorsing bevestig die feit dat Jesus gesterf het, en dit sou maklik wees om te stel dat Jesus ware mens is omdat Hy gesterf het. Op metafisiese vlak kan daar egter gestel word dat indien die opstanding emstig opgeneem word, daar 'n probleem is aangesien dood by implikasie onomkeerbaar is. Die opstanding keer die dood om, en dan sou by wyse van terugskouing gestel word dat Jesus juis nie mens was nie.

Sterflikheid mag nie net a-fisies gesien word nie. Die mens het vryheid van keuse. Die mens misbruik hierdie vryheid tot selfverheffing - sonde, en die gevolg van die 
sonde is die dood. Dit beteken dat die mens se bestaan deur die dood ingeperk word. Daar kan egter nie met sekerheid gestel word dat die essensie van menslikheid sterflikheid is nie. Die leidraad tot die regte verstaan van Jesus se menslikheid lê in die feit dat Jesus in tyo gelewe en gesterwe het. Om sterflikheid as kriterium van menslikheid te gebruik is ' $n$ statiese benadering.

\subsection{Historiese menslikheid}

Een van die belangrike vooronderstellings van die ondersoek na die historiese Jesus is juis dat Jesus ten volle mens was en daarom aan 'n historiese ondersoek onderwerp kan word. Hierdie vooronderstelling is van besondere belang aangesien daar 'n besliste beeld van menslikheid agter hierdie vooronderstelling lê. Menslikheid en geskiedenis is skynbaar nou aan mekaar verbind. Pannenberg (1994) se siening van die geskiedenis sal verder ontgin moet word. Dit blyk die sinyolle keuse in die moderne era te wees. Daar word in hierdie artikel gekies vir twee sake wat gesien word as tekenend van menslikheid, naamlik geskiedenis en die mens se verhouding met God (vgl Heyns 1981:128). Die verhouding met God kan egter slegs binne die geskiedenis gesien word, en juis daarom word geskiedenis eerste genoem. Die aard van die verhouding tussen mens en God is egter meer as net histories en daarom sal dit ook bespreek moet word.

\subsubsection{Perspektivisme en pluralisme}

Daar word hier gepleit vir verskillende perspektiewe ten opsigte van dieselfde geskiedenis juis omdat die geskiedenis meer as een verhaal vertel. Die pluralisme van die postmodernisme is 'n probleem waarvan deeglik kennis geneem moet word en daar moet seker gemaak word dat daar nie in 'n relativisme (kyk Brueggemann 1993:10) verval word nie. Dit beteken egter nie dat daar nie ruimte is vir meer as een interpretasie nie.

Enige uitspraak aangaande die mens wat nie ems maak met die historiese gesitucerdheid van die mens nie, loop gevaar om te verval in irrelevante spekulasie. Daar sal later teruggekom moet word op die dialektiese aard van die geskiedenis, aangesien Pannenberg (1994:300) dit reg het wanneer hy stel dat God slegs deur die geskiedenis geken kan word. Dit is nie moontlik om by wyse van metafisiese spekulasie by kennis van die ware God uit te kom nie. Perspektief - in gedeeltelike aansluiting by Brueggemann (1993:12) - is van groot belang in enige benadering, en geskiedenis is oop tot meer as een perspektief. 


\subsubsection{Historiese bepaaldheid as menslikheid}

Dit moet duidelik gestel word dat die mens se gesitueerdheid midde in die geskiedenis nie die wese van die mens weergee nie. Die transendente dimensie wat Kasper (1984: 266) so duidelik uitwys, 'mag nooit buite rekening gelaat word nie. Mense is altyd meer as hulle geskiedenis en het ook beheer oor die geskiedenis deur keuse van interpretasie. Die mens is ook meer as die geskiedenis in sy of haar strewe na meer en beter en in die perspektief op tyd in die sin dat geskiedenis self tot ' $n$ einde kom.

Menslikheid is nie net om deel van die geskiedenis te wees nie. Diere is deel van die geskiedenis, maar sou nooit as menslik beskryf kon word nie. Die belang van die soeke na die historiese Jesus kan met ander woorde nie net vanuit hierdie perspektief geregverdig word nie. Elke akademikus se konstruk van die historiese Jesus sal 'n eie beeld van menslikheid na vore laat tree. Tog is die menslike situasie vasgevang in die geskiedenis. Enige ondersoek na die historiese Jesus is self ook uitgelewer aan 'n eie historiese situasie. Terwyl 'n historiese ondersoek na enige mens moontlik is, beteken dit nie dat so ondersoek teologiese relevansie het nie. Die bemoedigende van die soeke na die historiese Jesus is die vooronderstelling dat Jesus mens midde in geskiedenis was. Dit kan ten minste teologies konstruktief gebruik word, al verskil die verskillende geleerdes se konstrukte van mekaar. Hulle beelde van wat menslik is, hang van hulle eie situasie af (vgl Brueggemann 1993:9).

\subsubsection{Wolfhart Pannenberg se historiese deelname}

Pannenberg (1994:300 vv) se teologie gee 'n verdere leidraad tot die regte verstaan van die saak. Dit is duidelik dat daar nie sprake kan wees van die daarstelling van 'n metafisiese hipotese van wie en wat die mens is nie. Elke konstruk kan vanuit ' $n$ ander perspektief gekritiseer word. 'n Voorbeeld hiervan is die feit dat elke teoloog iets anders uit Jesus se lewe haal om die essensie van Jesus raak te vat.

Om dan nou ' $n$ teologie van onder te bedryf beteken nie net om erns te maak met die feit dat Jesus mens geword het midde in die menslike geskiedenis nie, maar dit beteken ook om erns te maak met die feit dat die teoloog self in 'n eie historiese situasie vasgevang is. Daar is wel sprake van afstand, maar nooit kan daar totale afstand ten opsigte van die geskiedenis veronderstel word nie, die werking van die geskiedenis op die mens kan nie ontken of gekeer word nie (Ricoeur 1981:61). Die verstaan van Gadamer (kyk Carson 1996:68) se versmelting van horisonné gee iets weer van die konsep van die mens as historiese wese. In hierdie konsep is daar reeds die begin van 'n afstand wat wel ingeneem kan word om tot ' $n$ aanvaarbare perspektief te kom. Alhoewel dit volgens Carson (1996:120) nie altyd duidelik is of Gadamer sou wou praat van objektiewe waarheid nie, laat sy benadering die ruimte vir so 'n gedagte. 
Die onderskeid tussen 'n relativisme en histcriese perspektief moet duidelik gehandhaaf word. Die mens as deel van die geskiedenis beteken nie noodwendig dat die mens vasgevang word in 'n relativisme waaruit die mens nooit sal kan ontsnap nie. Die gedagte van die horison van die teks (historiese somtotaal van situasie, inhoud, intensie van die outeur en residie van die teks) en die horison van die leser kom bymekaar en die leser se uitkyk op die lewe verbreed.

Pannenberg se belangrike insig is dat teologie ems maak met die historiese aard en konteks van menslike bestaan, en vanuit hierdie perspektief teologie wil bedryf. Sy vooronderstelling bly steeds dat dit tog vir mense moontlik is om bo die tydeiike uit te styg en stellings te maak van breër toepassing as hulle eie situasie (Carson 1996:86). Hierdie aanname word hier gehandhaaf. Objektiewe uitsprake vind plaas binne 'n historiese konteks, maar word nie deur die konteks verswelg nie. 'n Volgende leser sal kan verstaan wat met die stelling bedoel word, al is dit anders verwoord.

Die menslikheid van elke mens is onlosmaaklik verbind aan die geskiedenis waarbinne daardie mens leef. Jesus as mens was deel van 'n sekere geskiedenis en Hy het 'n eie geskiedenis gehad. Jesus was deel van die menslike situasie. 'n Teologie var: onder erken hierdie gegewene en maak erns daarmee, sonder om te verval in 'n relativisme. Hieruit kan afgelei word dat elke nuwe situasie en elke nuwe geslag tot 'n nuwe verstaan van menslikheid kan kom, ook die menslikheid van Jesus. Dit is na so 'n dinamiese verstaan van die raamwerk van die Chalcedon formule waama gestreef word.

\subsubsection{Geskiedenis as konteks vir evaluasie van menswees}

Dit moet duidelik gestel word dat geskiedenis nie direk gelyk gestel kan word aan menslikheid nie. By wyse van metaforiese spreke kan daar gepraat word van geskiedenis as die verhoog waarbinne die menslike drama ontvou. Verskillende teoloë se benadering tot die geskiedenis van Jesus dien as illustrasie. Hierdie teoloē se benaderings word uitvoerig in die proefskrif 'Chalcedon op pad na die 21e ceu' (Otto 1997) behandel. Wat hier volg, is 'n opsomming van uiteenlopende standpunte.

\subsubsection{Hick}

Hick (1993:24) sien Jesus as 'n dinamiese man wat besig was met sosiale verandering. Jesus se pogings tot 'n sosiale verandering kenmerk sy lewe. Die gelykenisse word gesien as subversiewe wysheid wat die wysheid van die dag uitdaag tot 'n nuwe verstaan. Die wonders word op horisontale vlak as sosiale gebeurtenisse interpreteer. Die uniekheid van Jesus word vervlak tot 'n menslikheid wat voorbeeldig van aard is. Jesus is nie werklik Seun van God nie, maar weens sy intieme verhouding met God (diepe be- 
wussyn van God) wys hy die weg aan die res van die mensdom aan. Jesus se lewe kom as gevolg van die radikale van sy sosiale agenda tot 'n einde aan die kruis en sy volgelinge sit die beweging wat Jesus begin het voort.

Vir hierdie teoloë kom Jesus se menslikheid daarop neer dat Hy 'n besondere mens was (kyk ook Van Aarde 1995b) wat 'n besondere teenwoordigheid kon handhaaf. Jesus is soos die Griekse sinici 'siener' wat deur alternatiewe wysheid die samelewing op die kop keer (kyk Borg 1995:30). Sonder om te beweer dat Nuwe-Testamentici soos Van Aarde of Borg dit doen, kan gestel word dat historiese ondersoekers, meegevoer deur die relatiewe van die postmodernisme, die historiese Jesus kan beperk tot 'n mens met niks meer as menslike impak nie. Die 'point of view' van die postmodernisme kan dit moontlik maak dat daar 'n godsdiensgelykheid veronderstel word, wat tot gevolg het dat die historiese Jesus minder word as wat $\mathrm{Hy}$, ontologies gesien, was.

\subsubsection{Walter Kasper}

Net soos by die vorige denkers is Kasper (1984:50) se uitbeelding van die menslikheid van Jesus baie sterk gebonde aan die lewe van Jesus, met die klem op 'n pneumatologiese beradering. Dit is egter veral Jesus se dood wat besondere aandag kry by Kasper se beeld van Jesus se menslikheid. Jesus se boodskap, sy wonderwerke, en Jesus se selfgetuienis is almal deel van die menslikheid van Jesus. Kasper sien die menslikheid van Jesus met ander woorde baie meer omvattend. Sy klem op die dood van Jesus as teken van menslikheid is van besondere belang angesien dit die ruimte word vir die hantering van die sonde. Sy grootste winspunt bly egter die totale benadering wat hy volg in sy hantering van die menslikheid van Jesus. Kasper se mensbeeld is egter staties. Die dinamiese aard van menswees kom nie altyd duidelik na vore by sy uitbeelding van die menslikheid van Jesus nie.

\subsubsection{Wolfhart Pannenberg}

Alhoewel Pannenberg (1994) met 'n teologie van onder werk is dit opvallend dat sy klem nie lê by aspekte van Jesus se lewe nie, maar dat Jesus as die nuwe Adam getipeer word wat die nuwe mensdom inlei. Pannenberg maak die meeste van die mens wat vasgevang is in die historiese werklikheid. Die menslikheid van Jesus is iets wat in die geskiedenis teruggevind kan word. Die menslikheid van Jesus en van elke ander mens is egter meerduidig by Pannenberg (1994:294). Jesus as die ideale mens wys op 'n tekort wat daar in menslike bestaan was. Die mens is nie in teenstelling met God nie, maar daar is sprake van die Goddelike vonk in die mens, al vertel die geskiedenis die verhaal van botsing tussen God en mens. In die denke van Pannenberg (1994:277) is 
Jesus se menslikheid met ander woorde nou verbind aan sy historisiteit. Jesus is gelyk ook die een wat die nuwe geskiedenis inwy en die nuwe mensdom aankondig.

Hierdie aspek van die mens is eintlik die mens wat bokant sy of haar situasie uitstyg, om ' $n$ belangrike aspek van menswees te beklemtoon. ' $n$ Mens is oo' meer as die historiese situasie en altyd besig om sigself te projekteer. Jesus is net die eerste mens wat Homself reg projekteer. In hierdie geval sou daar dan gestel kon word dat daar meer van menswees teenwoordig was by Jesus, juis omdat Hy die regte keuse gemaak het. Jesus wys die pad na volle menswees voor God aan. In Jesus kom die Goddelike bedoeling met menswees die geskiedenis binne. 'n Tweede geskiedenis loon nou naas die sondige menslike geskiedenis, en dit is die menslike geskiedenis van regverdig lewe voor God.

Die gevolgtrekking waartoe gekom kan word, is dat Jesus se menslikheid deur verskillende mense binne die konteks van sy eie geskiedenis anders verstaan is. Almal van hulle het egter aansluiting gevind by die geskiedenis. Nie almal het dieselfde bronne gebruik nie, maar dieselfde man is vanuit verskillende perspektiewe benader.

\subsubsection{Volle historiese perspektief}

Van de Beek (1996:86) se beeld van menslikheid moet ook hierby genoem word. Alhoewel hy binne die konteks van 'n skeppingsteologie praat, maak hy 'n geldige punt wanneer hy stel dat Jesus ten volle mens was, tot op die punt waar daar gestel kan word dat die mens ' $n$ afstammeling van die ape is (Van de Beek 1996:112). Hierdie punt moet gelyk gegee word in die sin dat indien die evolusie deel van die menslike. geskiedenis is, daarmee erken word dat Jesus ook deel van hierdie geskiedenis is.

Van de Beek (1996:165) se aandrang daarop dat Jesus se gene nie spesiaal was nie en dat gestel moet word dat Jesus homo sapiens sapiens was, kan nie onderbeklemtoon word nie. Jesus was nie homo sapiens Christus of dalk homo Christus nie, Hy was homo sapiens sapiens. Jesus was mens soos enige ander mens. Hy was nie geneties beter as sy tydgenote nie. Indien sy gene wel beskikbaar sou wees, sou daar nie daarmee 'n beter mens gekloon kon word nie. Jesus se menswees is deelname in die volle spektrum van menswees. Dit is nie net gedeeltelik nie. Daar kan gestel word dat die volle impak van menswees, van argeologiese implikasie, tot intieme persoonlike denke en strewes soos verwoord in sielkundige denke, in Jesus teruggevind kan word.

Van de Beek se mensbeeld is ' $n$ beeld wat hy vanuit sy skeppingsteologie aflei. Daar is sekere aspekte van menswees wat uit hierdie denke na vore tree wat die saak van menswees in perspektief stel. Die eerste belangrike punt is dat God nie net 'n behae in die mens het nie, maar die mens wil, die mens is die gevolg van 'n Goddelike wilsbesluit. Die mens se daar-wees is 'n wilsbesluit van God (Van de Beek 1996:274). 
Hierdie geskapenheid impliseer saam met die gewil wees (God wil die mens) dat die mens ook begrens word (Van de Beek 1996:278). Die mens is aan transisies onderwerp (soos die dood). Om begrens te word, is om 'n las te dra, aangesien daar onderhorigheid deur hierdie konsep veronderstel word. Omdat die mens deur God gewil word, beteken dit ook dat die mens gewild is.

Tweedens moet gestel word dat die mens na God se beeld geskep is (Van de Beek 1996:280). Genesis 1 stel dit duidelik genoeg. Daarmee saam kan Psalm 8:5, 6 se vraag en antwoord gestel word, die mens is na God se beeld geskep, skaars minder as 'n hemelse wese (iets van die Goddelike vonk wat ons ook by Pannenberg terugvind). Sodra daar verstaan word dat die mens na God se beeld geskep is, kan daar begryp word dat die mens deur God heen geken kan word. Dit verbind die mens en God aan mekaar. Van de Beek (1996:285) is daarvan cortuig dat beeld baie met die begrip van skaduwee te doen het en daarom met beskerming.

Die mens is nie alleen geskep nie (Gen 2). Op spoor van Barth stel Van de Beek (1996:291) dat die mens in verhouding staan. Dit is nie goed dat die mens alleen is nie, die mens het ' $n$ vennoot nodig. Die meervoudigheid van die mens is nie toevallig nie, maar ' $n$ deel van die geskape werklikheid. Sonde is deel van menslike bestaan. Van de Beek (1996:309) stel vier sake aangaande die feit dat sonde en menslike bestaan aan mekaar gekoppel is. Sonde is menslike skuld en kan nie verwyder word nie, dit bly staan. Sonde is ' $n$ lot wat alle mense tref, elke mens is slagoffer van sy of haar omgewing en daarom slagoffer van sonde. Derdens kan gestel word dat sonde iets is wat nie daar behoort te wees nie. God het die mens met 'n vrye keuse geskep, die mens het met die verkeerde keuse die sonde in die skepping ingebring. Dit beteken in die laaste instansie dat sonde iets met God te doen het. God keer in liefde die sondige situasie om en red die mens.

\subsection{Mens in verhouding met God}

Die mens staan in verhouding tot God, midde in die geskiedenis. Hierdie verhouding kom op twee vlakke na vore. Die mens is deel van die skepping, en die mens kies hoedanig die verhouding met God sal wees. Pannenberg (1994:318) sien Jesus as die hoogtepunt waarop die geskiedenis afstuur. Die skepping se doel word bereik op grond van wat Jesus gedoen het. Daar word in hierdie artikel gestel dat die mens se skepping deur God eerstens onder die teken van die verhouding met God staan, en nie onder die teken van die geskiedenis nie. Daarmee word bedoel dat die geskiedenis wel die ontplooiing van die verhouding tussen God en mens is, maar dat hierdie verhouding neerslag in die skepping vind. Die skepping van die mens is die begin van die verhouding met God, en die geskiedenis vertel die verhaal van hoe hierdie verhouding verloop het. 


\subsubsection{Verhouding as deel van die skepping}

Hiermee word bedoel dat mense hulle verhouding met God as 'n gegewene ontvang. Elke mens is 'n skepsel en daarom met hierdie verhouding geseèn. As deel van God se skepping, en as mens wat deur God gewil is, kan die mens nie van hierdie verhouding ontsnap nie. Hierdie verhouding strek verder as die historiese. Dit is veral hierdie aspek wat maak dat die mens as wese in verhouding met God, eers skeppingsmatig gestel moet word. Deel van die denkraamwerk van die Christendom is die eskatologiese perspektief, dit wil sê die einde van die geskiedenis. Na die geskiedenis, by die opstanding, sal die mens steeds as skepsel in verhouding met God wees, buite enige geskiedenis om heen.

\subsubsection{Verhouding by wyse van keuse}

Die mens is egter ook ten volle deel van die geskiedenis. Vanuit 'n sekere perspektief kan gestel word dat die geskiedenis die verhouding tussen God en mens boekstaaf met behulp van een van die temas wat na vore kom: die mens se keuse vir of teen God. Die begrip van sonde maak dit duidelik dat die mens se keuse meestal aan die kant van sonde, dit wil sê teen God, lê. Dit is moontlik om dieselfde geskiedenis vanuit meer as een perspektief te benader en tot verskillende gevolgtrekkings te kom oor die vraag wie en wat die mens is en wat die mens gedoen het. Mense staan egter altyd binne die geskiedenis, ook die geskiedenis wat hulle wil interpreteer. Dit is duidelik dat dit moontlik is om elke beeld van die kern van menswees histories te motiveer.

\subsection{Ware mens}

Jesus se menslikheid is al vanuit verskillende perspektiewe gemotiveer; vanaf die liggaamlike, tot die emosionele. Elke nuwe geslag behoort op grond van die eietydse beeld van die wêrreld en die werklikheid die konsep van menslikheid op Jesus toe pas. Hierdie twee sake - die mens as geskape wese en as historiese wese - lyk na twee sake wat op 'n meer deurlopende grondslag toegepas kan word. Kenmerkend aan hierdie twee konsepte is dat dit die mens as totale wese benader kan word. Die verskillende benaderings van verskillende tye pas die kriteria verskillend toe, maar dieselfde resultaat gee egter aanduiding van die relevansie van dié deel van die Chalcedonformule. Jesus is en was vere homo. Die waarde van die Chalcedonformule lê daarin dat die ware menslikheid van Jesus bevestig word.

Chalcedon gee met ander woorde die agtergrond, die spreekreëls vir die hantering van die gesprek rondom die mensheid van Jesus. Evolusie en vooruitgang, verandering van paradigma en die verloop van die geskiedenis saam, maak dat dit nie werklik 
moontlik is om 'n vaste (statiese) beeld van menslikheid daar te stel nie. Jesus se menslikheid moet dus meer dinamies verstaan word om in elke nuwe situasie steeds relevant ervaar te word.

\section{GODDELIKHEID VAN JESUS}

Die Goddelikheid van Jesus is die tweede aspek van die Chalcedonformule wat hier hanteer moet word. Soos met die menslikheid moet daar tog iets van die mens se verstaan van God se Goddelikheid gestel word alvorens gestel kan word dat Jesus ware God is. Die mens is altyd in verhouding met God en praat eerstens met God. Dit is nie so maklik om oor God te praat nie (vgl Weber 1981:181).

Daar is ook sekere gevare aan die saak verbonde. Elke geslag stel op 'n eie manier die saak van God en Jesus se Goddelikheid. Selfs die kanon gee reeds aanduiding hiervan. Terwyl die sinoptiese evangelies na Jesus se Goddelikheid wys deur na onder andere na wonderwerke te verwys is Jesus se alwetenheid en selfgetuienis by die Johannes-evangelie (kyk Joh 14-17) belangrik. Ander skrywers stel dat die sleutel tot die verstaan van Jesus se Goddelikheid teruggevind word by die opstanding en verhoging deur God (kyk Flp 2). Oor een saak is daar eensgesindheid, midde in die verskille, en dit is dat Jesus Seun van God is. Hierdie standpunt moet in teologie verdiskonteer word. Jesus se Goddelikheid kan teruggevoer word na die opstanding, maar die interpretasie van hierdie gegewene verskil.

Aan die een kant kan daar gepoog word om te onderskei tussen essensiële eienskappe teenoor toevallige eienskappe, en dan Jesus aan hierdie eienskappe te meet. .Die gevaar is dan altyd dat daar eienskappe geïdentifiseer sal word na aanleiding van wat Jesus dan wel was. Aan die ander kant kan algemene beginsels gestel word en Jesus dan hieraan gemeet word. Die probleem met so 'n benadering is goed deur Hick (1993) uitgebuit.

Dit sou moontlik wees om soos Morris (1987) op 'n logiese manier Jesus se inkarnasie te bewys. Daarmee is daar net soveel probleme. Dit is verdag om - maak nie saak watter logika gebruik word nie - op metafisiese manier Goddelike eienskappe te stel en dan logies aan te dui dat so iets moontlik is.

\subsection{Metaforiese denke}

Die eerste saak wat gestel moet word wanneer ook al oor (met) God gepraat word, is dat die mens in gebreke bly om enige saak na wense te verwoord. Die gebrekkigheid van menslike spreke maak dit net nie 'n geskikte werktuig om te gebruik nie. Die metafoor is die verleentheidstaal wat gebruik word in die poging om die onbeskryflike te 
beskryf. Tog kan daar aanvaar word dat 'n saak wel verwoord kan word, anders sal die metafoor nie gebruik word nie (Van Wyk 1995:519). Dit is 'n gevaarlike stelling om te maak deur die metafoor te vervlak tot hierdie een gebruik wat so pas genoem is. Juis daarom word hiermee slegs bedoel dat die metafoor werktuig is in die mens se hand wat gebruik word om iets aangaande God te kan stel. Die metafoor kan inderdaad gebruik word om die waarheid te verwoord en te propageer (Van Wyk 1995:536).

\subsubsection{Metaforiese spreke en geskiedenis}

Die metafoor as teken van onvermoë moet nie verwar word met historiese of fisiese werklikheid nie. Die metafoor is in 'n sekere sin ontoepaslike taalgebruik (McFague 1987:33) om iets te stel wat nie maklik (of dalk glad nie) op 'n ander manier gestel kan word nie. 'n Metafoor kan ter versagting gebruik word (byvoorbeeld 'die ontslapenes sal in die nasate se gedagtes voortleef, wat eintlik beteken dat die kinders die ouers wat dood is, sal onthou). Dood word versag met die metafoor 'ontslapene'. Dit neem die werklikheid wat deur hierdie metafoor gestel word, nie weg nie. Metafoor en werklikheid is nie noodwendig van mekaar vervreem nie; daar is altyd meer as wat in die metafoor gestel word, maar die metafoor is nie verwyderd van die wêreld nie. Toegepas op die huidige bespreking kan dit gestel word dat enige metafoor wat gebruik word om 'n historiese werklikheid te beskryf, nie 'n aanspraak op die waarheid of werklikheid opsê nie.

Hierdie belangrike aspek van die metafoor is veral van belang by die een saak wat in hierdie deel van die bespreking na vore tree, naamlik die opstanding van Jesus. .Die metaforiese-dimensie van die woord 'opstanding' kan duidelik gemaak word deur te stel dat dit ook 'opwekking' genoem kan word, maar nie 'resussitasie' nie. 'Opstanding van Jesus' is 'n metafoor in die sin dat die mens nie alles wat daar gebeur het, kan beskryf nie, maar dit beteken nie dat enige aanspraak op die werklikheid van so 'n gebeurtenis opgesê word nie. Inteendeel, die blote stelling dui op 'n historiese aanspraak (Pannenberg 1994:360), 'Ontslapene' as metafoor vir dood en 'opstanding' as metafoor vir wat met Jesus gebeur het, staan op dieselfde vlak in terme van aanspraak op waarheid. Vervolgens word daar in die res van hierdie gedeelte van metafore gebruik gemaak, soos lank reeds gedoen is, sonder om een aks van die aanspraak op die waarheid agterweê te laat.

Die vraag is na die volgorde van hierdie spreke en die gevolglike inhoud daarvan. Dit sou kon gebeur dat daar op grond van 'n 'ingebore' bewussyn kennis geneem kan word van God. In die geval oordink die mens dit wat ingeplant is. Dit kan egter wees dat God ervaar word in die lewe, en hierdie ervaring dan oordink word, wat dan by 
wyse van metafore gestel word (McFague 1987:39). Die eerste denkrigting se klem is metafisies, en die twee se klem is histories beskrywend.

\subsection{Metafisiese ontologie}

Metafisiese ontologie verwys na 'n denkraamwerk waarbinne 'n bewussyn van die Goddelike in die mens ingeplant is (Pannenberg 1991:141). Hegel sien dit as ' $n$ teenwoordigheid van die Absolute wese in die mens se bewussyn, wat moet groei tot geloof (Küng 1987:247). Daar is verskeie ander maniere om dit te beskryf, maar enige van die verskillende benaderings kom neer op metafisiese spekulasie en menslike projeksie.

'n Paar voorbeelde sal voldoende wees om hierdie saak te illustreer. Eienskappe wat na aanleiding van spekulasie aan God toegedig word, is die sogenaamde absolute eienskappe. Onsterflikheid, alomteenwoordigheid, alwetenheid, en almag tel onder hierdie eienskappe. Sodra die eienskappe dan gestel is, word gesê dat dit die essensie van Goddelikheid is (Swinburne 1989:54). Een van die resultate van so 'n benadering is dat dit maklik uitloop op 'n deisme, 'n vreemde, onbetrokke God.

Die grootste probleem met metafisiese spekulasie is dat die Goddelikheid van Jesus onder gedrang kom. Daar moet daarteen gewaak word om Goddelikheid op so 'n spekulatiewe wyse te probeer vasstel. Dit kan net wees dat die mens in die proses van spekulasie selfs die God van die Bybel agterlaat en uitkom by ' $n$ mensgemaakte god. Inkarnasieteologie kan ook binne hierdie konteks genoem word. Inkarnasieteologie as annvangspunt vir die Christologie loop uit op probleme wat selfs die Chalcedonformule in gedrang kan bring.

\subsection{Historiese ontologie}

Pannenberg (1991:159) stel dat die vrang na die waarheid van stellings aangaande God konkrete bevestiging vind in ervaring van die wêreld soos die wêreld en die mensdom blyke toon daarvan dat dit deur God bepaal word. Met hierdie enkele sin word in 'n mate die weg 'n beskeie verstann van God uitgestip. God kan slegs iangs een weg geken word. Hierdie cen weg is tenug te vind in die geskiedenis en die menslike ervaring van God in die geskiedenis.

Van de Beek (1996:233) se denkraamwerk maak dit moeilik om vanuit 'n historiese benadering tot die verstaan van die syn van God te kom. Skepping kan in 'n sekere konteks as blote spekulasie gesien word van dit wat die mens as sy of haar oorsprong wil sien. Die menslike ervaring van die skepping en die mens se pogings om sin te maak van die skepping vind egter nie in 'n vakuum plaas nie, maar midde in die proses van die geskiedenis. Van de Beek (1996:155) stel self dat 'n skeppingsleer 
spreke is oor die mens se verhouding met God, 'n verhouding wat net in die geskiedenis tot uitdrukking kan kom. Jesus is self ook by hierdie proses betrokke as die Middelaar.

Otto Weber (1981:397) beskrywe die essensie van God, asook God se eienskappe, binne 'n historiese raamwerk waar God Godself aan die mens openbaar. God tree in die geskiedenis in verhouding met die mens. God tree in verbinding met die mens uit vrye wil, maar bly tog ten volle God (Weber 1981:401). Hierdie vrye skakeling van God met die mens word 'openbaring' genoem en vind in die leefwêreld van die mens plaas. Binne die raamwerk van Weber $(1981: 411)$ kan gestel word dat die mens in reaksie op hierdie ontmoeting relasionele eienskappe aan God toedig. Dit is slegs vir die mens moontlik om in terme van hierdie relasionele eienskappe van God te praat. God se naam dui op God se selfmanifestasie in die geskiedenis (Weber 1981:419). God as die liefdevolle Een, God as die absoluut vry Een, en God as die Skepper is die eienskappe wat Weber noem in sy benadering tot die Goddelikheid van God. Die liefde van God en 'God is liefde' word deur Jüngel (1983:388) tot die uiterste gevoer in sy betoog dat die essensie van God in een woord gestel kan word, naamlik die liefde. Al hierdie eienskappe het in die verloop van die geskiedenis na vore getree. Dit is na aanleiding van konkrete ervaring en die nabetragting van die ervaring dat daar tot die gevolgtrekking gekom is dat sekere ontologiese uitsprake aangaande die syn van God gemaak kan word.

\subsection{Ontologie sonder openbaring?}

Die historiese benadering dui op ' $n$ teologie van onder. Dit is net nie moontlik om op spekulatiewe metafisiese manier te kom by 'n punt waar daar gestel kan word dat 'n stelling die essensie van God weergee nie. So 'n teologie van onder het natuurlik die perspektief van bo, nie as aanvullende perspektief nie, maar as meta-raamwerk waarbinne die teologie van onder worstel om 'n ontologiese uitspraak aangaande God te maak. Daar is doelbewus gebruik gemaak van die term 'ontologies' om daardeur aan te dui dat die metaforiese spreke steeds 'n emstige waarheidsaanspraak wil maak.

Die eerste voorwaarde vir so 'n teologie van onder is dat daar sprake moet wees van God se selfopenbaring in die geskiedenis. Sonder hierdie openbaring sou dit ook blote spekulasie wees. Dit kan genoem word ingrype in die geskiedenis, of openbaring, maar die punt is dat dit God is wat God self bekend maak aan die mens. Hierdie wete word nie onmiddellik aan die mens gegee nie, dit is by wyse van nabetragting dat besef word dat God met die mens in aanraking was. Hierdie nabetragting word in die Bybel teruggevind en 'n teologie wat meer erns maak met Bybelinhoude sal baie probleme van spekulasie vermy (kyk Frame 1995:235). 
Teen hierdie agtergrond kan daar nou weer ernstig gekyk word na die stelling dat Jesus Goddelik is. Hierdie stelling sal nou nie in terme van die eienskappe beskryf word nie, maar sal begrond word in ' $n$ historiese gebeurtenis waarin die gelowige stel dat hy of sy in ontmoeting met God getree het, of dat God God self in die geskiedenis van Jesus op 'n besondere manier geopenbaar het. Hierdie benadering stel nie 'n versameling van eienskappe en meet Jesus dan aan hierdie eienskappe nie, maar vra na die relevansie van ' $n$ besondere gebeurtenis. Na so 'n ervaring met Jesus het mense gekom tot die slotsom 'Ek het God ontmoet.'

\subsection{Ware God}

Indien dit nie metodologies deug om eienskappe vas te stel en dan te vra na Jesus en in hoe verre Jesus aan hierdie eienskappe voldoen nie, moet daar tog nog gevra word na die Goddelikheid van Jesus en die houdbaarheid van die kerk se belydenis en die Chalcedonformule se aandrang dat Jesus ware God is. Daar is reeds gestel dat dit metodologies die minste probleme oplewer wanneer na die historiese gekyk word en daaruit 'n afleiding gemaak word. In die geval van Jesus as God kan dit ook nie anders nie. Die vraag is dan na die besondere gebeurtenis, of reeks gebeurtenisse wat aanleiding gegee het daartoe dat Jesus as ware God beskryf word.

Saam met Pannenberg (1994) word hier gestel dat die oomblik van openbaring die duidelikste sigbaar is by die opstanding. Hierdie gebeurtenis is die spil waarom die hele konsep van Jesus se Goddelikheid wentel. Dit sou nie aanvaarbaar wees om na 'n Christus-gebeure te verwys en daarmee 'n otbepaalde proses te bedoel nie (kyk Macquarrie 1981:79). Dit is waarskynlik moontlik om Jesus se Goddelikheid terug te vind by ander aspekte van sy lewe, maar die dubbele betekenis van sodanige gebeurtenisse maak so 'n onderneming riskant. Die opstanding is die een gebeurtenis wat nie aan hierdie meerdere interpretasies blootgestel is nie. Dit moet egter gestel word dat hierdie vertrekpunt slegs beskikbaar is aan die teoloog wat oortuig is van die historiese werklikheid van die opstanding. Sonder hierdie oortuiging kan daar myns insiens slegs van 'n afgewaterde Goddelikheid of iets dergliks gepraat word. Persone soos Hick wat die opstanding totaal verwerp, kan dan ook nooit by 'n konsep van ware Goddelikheid uitkom nie. Jesus is en sal in so ' $n$ benadering net 'n sosiale ingenieur bly. Jesus is nie 'Seuh van God' omdat Hy in die eerste plek intens bewus was van God se teenwoordigheid in sy lewe nie (kyk Van Aarde 1995b:629). Jesus is eerstens Seun van God omdat Hy uit die dood opgewek is.

Die saak van die opstanding is onder andere ook 'n saak van geloof. Die teoloog moet kies vir of teen die insluiting van die opstanding van Jesus as deel van 'n historiese ondersoek. Die kerk het egter van vroeg af reeds gekies vir die opstanding as integrale deel van 'n historiese verstaan van Jesus (Schweizer 1987:13). Die opstan- 
ding/opwekking van Jesus is die metafoor wat tradisioneel gebruik is en wat hier gehandhaaf word. Die metafoor verwys in meer as een opsig na 'n werklikheid in die verlede. Dit is egter nie op daardie vlak wat hierdie metafoor funksioneer nie. Die opstanding as metafoor verwys na 'n gebeurtenis wat in die verlede afgehandel is en waarvan die resultaat bekend is, maar die aard van die gebeurtenis is in geheimenis gehul (kyk Brown 1994:163). Wat hierby bedoel word is die volgende:

Jesus het gesterf en is begrawe. 'n Ruk later was die graf leeg. Die lyk was nie daar nie. Hierdie feit kon deur 'n enkele reis na die graf verkeerd bewys word, maar omdat dit nie die geval was nie, beteken dit dat die graf inderdaad leeg was. Die Jode en die Christene verskil nie oor die moontlikheid van die leegheid van die graf nie, maar wel oor die rede vir die leegheid van die graf. Op sigself is hierdie stuk inligting nie voldoende rede vir die gevolgtrekking waartoe die kerk gekom het nie. Die leë graf is geen bewys van die opstanding nie (Küng 1992:103). Daar is 'n tweede, in baie opsigte meer belangrike, stuk inligting wat die kerk genoop het om die metafoor 'opstanding' te begin gebruik.

Die belangrike gegewene is die verskyning van Jesus aan verskeie ooggetuies. Daar hoef nie gespekuleer te word oor die tydperk tussen opstanding, hemelvaart en verskynings nie, ook nie oor die volgorde nie. Die kern van die saak is dat Jesus aan volgelinge verskyn het en dat hulle onmiddellike reaksie hierop geloof was. Die getuienis aangaande die verskyning van Jesus is die tweede rede vir die kerk se gebruik van die metafoor 'opstanding'. Geen dissipel of ander volgeling het fisies die gebeurtenis gesien nie, en tog is daar, op grond van die resultate tot hulle beskikking, eenstemmigheid dat daar 'n Goddelike wonder plaasgevind het.

Hierdie 'opstanding' was nie net 'n wonder nie. Die kerk reageer op hierdie gebeurtenis met die belydenis 'Jesus is Here.' Die opstanding dui finaal aan wie Jesus is (Crawford 1985:48). Hierdie eenvoudige belydenis stel dat Jesus in die oë van die kerk God is. Die opstanding is met ander woorde gesien as God se regverdigverklaring van Jesus. Hierdie een besondere historiese gebeurtenis bring die mens sover om te stel dat hy God ontmoet het. Jesus se Goddelikheid word primêr teruggevind in sy opstanding uit die dood.

Daar is natuurlik baie probleme wat steeds nie so maklik opgelos kan word nie, maar hierdie is ' $n$ goeie beginpunt vir ' $n$ Christologie wat in hierdie eeu steeds wil bely dat Jesus die Here is. Jesus se Goddelikheid word by die opstanding begin en gefundeer. Daar is natuurlik sekere implikasies, maar dit is implikasies van hierdie een historiese gebeurtenis. So byvoorbeeld is die maagdelike geboorte nie 'n bewys van die Goddelikheid van Jesus nie, maar iets wat afgelei word van die opstandingsgebeure. Jesus se Goddelikheid impliseer dat dit wat in Jesus gebeur het, op Goddelike inisiatief 
moet wees, omdat die mens sondaar is. Jesus se geboorte kan daarom nie 'n toevalligheid of menslike inisiatief wees nie, maar 'n daad van God en derhalwe 'n maagdelike geboorte.

Teenoor Bornkamm (1996:180) moet gestel word dat hierdie gebeurtenis (die opstanding) nie buite die geskiedenis lê nie. In terme van tyd kan die opstanding kronologies gestel word binne die verloop van die geskiedenis. God se selfgetuienis van 'n bestaan buite tyd om maak dit nodig om te stel dat Jesus deel het aan hierdie buite-tyd bestaan (tradisionele term: ewigheid). Daaruit kom die inkarnasiedenke na vore. Die inkarnasiedenke is nie die begin van 'n teologiese denkproses nie, maar die resultaat van nadenke aangaande die opstanding.

Tot op ' n sekere punt kan daar met Küng (1992:111) saamgestem word dat die opstanding nie 'n openbare feit was nie. Daar moet egter van hom verskil word wanneer hy stel dat die opstanding buite die historiese lê, aangesien Jesus buite tyd getree het. Dit is waar dat Jesus buite tyd getree het, maar menslik kronologies gesproke, kan die gebeurtenis aangedui word.

In die vorige paragraaf is daar verwys na buite-tyd bestaan. Hierdie enkele saak kan nou gebruik word om die verskil in benadering verder te illustreer. Tradisioneel was die probleem dat die ewigheid/onsterflikheid van God as 'n eienskap gesien is wat op metafisiese wyse afgelei word. Jesus is daaraan gemeet (Hick) en daar is bevind dat Jesus nie aan die vereiste voldoen nie. 'n Historiese benadering wat kyk na dit wat in die Bybel staan (veral die skeppingsteologie) maak dat daar eerder gepraat moet word van God as buite-tyd, met die mag om tyd ook te deurbreek. God is in beheer van tyd, nie slagoffer van menslike liniêre denke wat wil praat van ewigheid nie. Indien die opstanding dien as gebeurtenis wat aandui dat Jesus God is, beteken dit dat daar vanuit hierdie gegewene na Jesus en tyd gekyk kan word. Indien God in beheer van tyd is, beteken dit dat God buite tyd kan bestaan maar ook ten volle deel van tyd kan wees. Dit is met ander woorde nou moontlik om te stel dat Jesus se tydsbestaan nie veroorsaak dat Jesus nie Goddelik kan wees nie. Verder beteken die opstanding dat Jesus tyd orwin het deur die opstandingsgebeure, en buite tyd kon tree. Die opstanding bewys Jesus se beheer oor tyd en daarom sy Goddelikheid. Die opstanding is gelyk ook die aanbreek van die nuwe era, selfs al is dit nog versluierd (Barth 1979:123).

Daar kan met sekerheid gestel word dat Jesus ware God is op grond van die historisiteit van die opstanding. Hierdie gebeurtenis is die primêre bewys dat Jesus vere Deus is. Elke nuwe geslag sal klem lê op ander aspekte van die wonderlike werklikheid van God, sonder om weg te neem dat Jesus ware God is. 'n Teologie van onder as 'n teologie wat die historiese as uitgangspunt neem, blyk 'n voortreflike benadering te wees om te kan staan by die ware Goddelikheid van Jesus.

By wyse van terugprojeksie kom daar steeds sake na vore wat uitgelê sal moet word. Indien Jesus ware God is, het Jesus gely na sy Godheid, het Jesus gesterf na sy 
Godheid. Leontus (kyk Meyendorf 1975:78) het vroeg reeds gestel dat een van die Triniteit gely en gesterf het. In die beantwoording van so 'n vraag sal daar altyd weer gewaak moet word teen metafisiese spekulasie. Moltmann (1990:167) stel dat die Seun van God in godverlatenheid gesterf het.

Jesus se Goddelikheid moet met ander woorde meer dinamies verstaan word, soos ook sy menslikheid. Waar die bepaling van die menslikheid van Jesus baie vloeibaar is, is dieselfde in beperkte mate waar van sy Goddelikheid. Die opstanding is die een vaste punt wat nie deur 'n volgende geslag geignoreer kan word nie. Deur die ceue heen sal dit die vaste punt wees vir die bevestiging dat Jesus Seun van God is. Wat wel sal verander, is die verstaan van God. Elke nuwe geslag sal ander aspekte van God beklemtoon na aanleiding van 'n eie situasie, en Jesus se Goddelikheid sal na aanleiding van dié verstaan geïnterpreteer word.

\section{WARE GOD EN WARE MENS}

Die eerste geloofsgemeenskap het sonder om te veel te dink oor die implikasies van hulle geloof, in verhouding met God, gelewe, oortuig daarvan dat Jesus die Seun van God is. Hulle was egter ook bewus daarvan dat Hy mens was wat saam met hulle gelewe het en voor hulle oē gesterf het. Uit hierdie twee stellings kom 'n medemenslikheids- en ' $n$ belewenis aspek na vore wat nog nie ontgin is in die denke aangaande die historiese Jesus nie. 'n Mens is ook mens deur ander mense heen. Jesus se gemeenskap het geen probleem gehad om Hom as mens te sien nie. Die teendeel is waar, hulle het tot en met sy dood aan hom as net nog 'n mens gedink. Dieselfde gemeenskap stel egter met vreugde, en met dieselfde cortuiging dat Jesus God is. Daar kan met ander woorde in afgeleide sin gestel word dat Jesus in die geskiedenis as mens ervaar is, en as God ervaar is. Alhoewel dit kronologies plaasgevind het, is dit nie kronologies verstaan nie, daarvan is die evangelies bewys. Die gelowiges het Jesus se menslike lewe begin oordink en God in die menslike Jesus teruggevind. Jesus as verskyning van God beteken nie dat God nou tot die fisiese beperk word nie (Van de Beek 1996:160). God se eer styg bo tyd uit. God is wel spesifiek teenwoordig in Jesus, maar nie uitsluitlik teenwoordig in Jesus nie.

Beide sake is vanuit verskillende perspektiewe benader, en dit sou moontlik wees om die verskillende geslagte se beelde van Goddelikheid en menslikheid weer te gee. Die punt wat egter duidelik na vore kom, is dat dit nie saak maak watter beeld deur 'n gemeenskap voorgehou is nie, dit kon op Jesus van toepassing gemaak word. Die eietydse formulering van die Chalcedonformule het altyd weer plaasgevind. Wat hierdie twee aspekte betref, is dit inderdaad so dat daar op spoor van Chalcedon met sekerheid gestel kan word dat Jesus ware mens en ware God is. Daar is 'n onlosmaaklike band tussen Jesus en Christus. Indien daar nie die kontinuïteit tussen 'gesterf aan die kruis' 
en 'aan die regterhand van die Vader' (met ander woorde opgestaan en opgevaar) veronderstel kan word nie, het die Christendom myns insiens geen bestaansreg nie (vgl Bockmuehl 1994:167). Die Chalcedonformule bied 'n agtergrond waarteen elke nuwe geslag se teologie getoets kan word en seker kan maak dat die eie beeld van wie en wat Jesus is, skeef getrek word nie. Sentraal tot hierdie saak is die kern van die geloof soos dit in die liturgiese na vore gekom het. Gelowiges is in die dood en opstanding van Jesus gedoop, nie in sy inkarnasie nie (O'Collins 1983:33). Die liturgiese gebruik van hierdie wete aangaande Jesus as ware God en ware mens bied 'n weg tot 'n meer dinamiese verstaan van Jesus se twee nature soos verwoord by Chalcedon.

Die dinamika van die verhouding tussen God en mens moet teen hierdie agtergrond verstaan word. Die radikale van hierdie saak kom daarin na vore dat daar nie eens van die dood van die mens Jesus gepraat kan word, sonder om ook iets van God te stel nie. Moltmann (1990:167) stel dit goed wanneer hy sê dat die paradoks waar is, naamlik Jesus, die Seun van God, het in godverlatenheid gesterf:

\section{GEVOLGTREKKING}

Dit is moontlik om steeds te praat van Jesus in terme wat herinner aan die formulering van Chalcedon. Die belangrikste voorwaarde is egter 'n meer dinamiese verstaan van die essensie van Jesus Christus. Die historiese verstaan van Jesus se bestaan bied hierdie dinamiese benadering, met die een voorbehoud, naamlik dat die opstanding as integrale deel van die geskiedenis van Jesus gesien word. Chalcedon bied in die oorgang tot die 21 e eeu steeds die spreekreëls vir sinvolle spreke oor Jesus van Nasaret.

\section{Literatuurverwysings}

Barth, K 1979. Dogmatics in outline. London: SCM.

Bockmuehl, M 1994. This Jesus: Martyr, Lord, Messiah. Edinburgh: T\&T Clark.

Brueggemann, W 1993. The Bible and postmodern imagination; Texts under negotiation. London: SCM.

Die Bybel 1983. 9e druk. Kaapstad: Die Bybelgenootskap van Suid-Afrika.

Frame, J M 1995. The Spirit and the scriptures, in Carson, D A \& Woorbridge, J D (eds), Hermeneutics, authority, and canon, 213-236. Grand Rapids, MI: Paternoster.

Heyns, J A 1981. Dogmatiek. Pretoria: NG Kerkboekhandel.

Hick, J 1993. The metaphor of God incarnate. Louisville: Westminster/John Knox. Jüngel, E 1983. God as the mystery of the world. Edinburgh: T \& T Clark.

Kasper, W 1993. Jesus the Christ. Louisville: John Knox.

Küng, H 1992. Credo: The apostles' creed explained for today. London: SCM. 
Küng, H 1986. The church. London: Search.

Moltmann, J 1974. The crucified God. London: SCM.

Meyendorff, J 1975. Christ in Eastern Christian thought. Athens (USA): St. Vladimir's Seminary press.

O'Collins, G 1983. Interpreting Jesus. London: Paulist Press.

Otto, J 1997. Chalcedon op pad na die 21 e eeu: 'n Soeke na 'n eietydse verwoording van die twee nature leer. DD-proefskrif, Universiteit van Pretoria.

Pannenberg, W 1994. Systematic Theology, Volume 2. Grand Rapids, MI: Eerdmans.

Ricoeur, P 1981. Essays on biblical interpretation, edited by L S Mudge. Philadelphia: Fortress.

Schweizer, E 1987. Jesus Christ: The man from Nazareth and the exalted Lord, ed by H Gloer. Georgia: Mercer University Press.

Schlink, E 1985. Ökumenische Dogmatik: Grundzüge. Göttingen: Vandenhoek \& Ruprecht.

Stumpf, E S 1975. Socrates to Sartre: A history of philosophy. New York: McGrawHill.

McFague, S 1987. Models of God. Philadelphia: Fortress.

Swinburne, R 1989. Could God become man? in Vesey, G (ed), The philosophy in Christianity. Cambridge: Press Syndicate.

Van de Beek, A 1996. Schepping: De Wereld als woorspel woor de eeuwigheid. Baarn: Callenbach.

Van Aarde, A 1995a. Kerk en teologie op pad na die derde millenium: Gedagtes oor die kontekstualisering van die dialektiese teologie in 'n plurale samelewing. HTS 51, 39-64.

1995b. Die historiese Jesus, die Jesus-beweging en die vorming van die kerk. HTS 51, 623-644.

Van Wyk, G M J 1995. Metafoor en waarheid. HTS 51, 517-538.

Weber, O 1981. Foundations of dogmatics, Volume 1. Grand Rapids, MI: Eerdmans. 1983. Foundations of dogmatics, Volume 2. Grand Rapids, MI: Eerdmans. 